\title{
Religious Freedom and the Law: A Reality or Pipe Dream for Prisoners in South Africa?
}

\author{
H. Puleng Motlalekgosi \\ motlalekgosid@tut.ac.za
}

\begin{abstract}
Freedom of religion, like other human rights, must be respected, protected, and promoted by relevant and entrusted authorities to comply with legitimate laws, applicable to a particular environment. In South Africa, the Correctional Services Act 111 of 1998 as amended, the White Paper on Corrections in South Africa of 2005, and internal policies are intended to make provision for prisoners' freedom of religion in the correctional services environment. These essentially give effect to the Constitution of the Republic of South Africa of 1996, emanating from pertinent international and African continental instruments. Through an analytic design of change over time, this essay seeks to conduct an analysis of prisoners' freedom of religion in South Africa. This analysis is based on the Department of Correctional Services' annual reports published between 1997 and 2016 and the general conditions of prisons in South Africa. The finding of this study reveals a violation of the right of prisoners to freedom of religion by the South African correctional authority.
\end{abstract}

Keywords: prisoners' freedom of religion, human dignity, religious beliefs, spiritual services, prisoners' spiritual needs

\section{Introduction}

Generally, people have a way of fulfilling their spiritual needs and aspirations. Irrespective of peoples' belief systems, like Christianity, Islam, Rastafari, or Satanism, people pray, and they praise and worship. This should be seen within the context of the principles of democracy, including a free society which can accommodate a variety of beliefs, a diversity of tastes and pursuits, customs, 


\section{H. Puleng Motlalekgosi}

and codes of conduct (Supreme Court of Canada 1985:336). In simpler terms, freedom of religion can be defined as the right of a person to believe in and practice whatever faith he or she chooses (Devenish 1999:163). The essence of the concept of freedom of religion is the right to entertain religious beliefs as a person chooses, the right to declare religious beliefs openly and without fear of hindrance or reprisal, and the right to manifest a religious belief by worship and practice or by teaching and dissemination (Supreme Court of Canada 1985:336).

The right to freedom of religion, like other rights, is also important to be afforded to inmates and to be protected and promoted by correctional authorities. This means that prisoners' freedom of religion holds the values of the residuum principle. Imprisonment is not an opportunity for the state to limit the rights and increase punishment further than what the court has intended (Muntingh 2007:10). In other words, while in prison, one has the right to observe and practice the religion of their choice.

In South Africa, the right to freedom of religion is protected by sections 15 and 31 of the Constitution of the Republic of South Africa of 1996 (South Africa 1996) and international laws. The protection, promotion and respect of prisoners' freedom of religion is not only a constitutional obligation of the Department of Correctional Services in South Africa, but also an obligation by virtue of being a member state of international organizations such as the United Nations (UN) (Dugard 2011:20) and the African Union (AU) (African Union 2019:6). This, by implication, means that the Department has the responsibility of making provision for the environment conducive for prisoners to observe and practice their religious beliefs - an environment that is consistent with the principles of human dignity.

Through its annual reports, the South African Department of Correctional Services seeks to suggest that it promotes and protects prisoners' freedom of religion while prison conditions such as overcrowding and staff shortages suggest otherwise. This essay conducts an analysis of the right of prisoners to freedom of religion. As a point of departure, it draws on the pertinent provisions of international African continental instruments and domestic laws and policies governing prisoners' freedom of religion in South Africa. This is done by means of an analytic design of change over time with the focus on the departmental annual reports published between 1997 and 2016 (Department of Correctional Services 1997; 1998; 1999; 2004; 2006; 2008; 2011a; 2014a; 2015a; 2016), and prison conditions. Lastly, this essay outlines 
the finding of the analysis of the status quo in respect of the prisoners' freedom of religion measured against prison conditions.

\section{Theoretical framework: South Africa's obligations in respect of the prisoners' freedom of religion}

In order to lay the basis for the analytical design of this article, it is important to outline the framework against which the status quo in respect of prisoners' freedom of religion in South Africa can be analyzed. This framework is developed from an international, African continental, and domestic law context and is based on a set of rules, general principles, treaties, conventions, charters, constitution, and legislation. These usually make provision for international human rights and are classified by many scholars as sources of international law (Mansell \& Openshaw 2013:17; Aust 2010:5; Dugard 2005:27).

\section{International law context}

While certain scholars contend that there is no agreed definition of what is meant by the term 'international law' (Mansell \& Openshaw 2013:6), there are some who offer definitions of this concept, developed in line with the era in which they live and their location. For instance, international law refers to a body of rules and principles which are binding upon states in their relations with one another. These rules and principles are increasingly important to the functioning of the interdependent world and include areas such as human rights, amongst others (Brierly 1963:1). Stratton (2009:1) defines it as the universal system of rules and principles concerning the relations between sovereign states, and relations between states and international organizations such as the UN. In addition to the definitions given above, international law is viewed as a body of law which also includes the rules of law relating to the functioning of international institutions or organizations, their relations with each other, and their relations with states and individuals, as well as certain rules of law relating to individuals and non-states so far as the rights or duties of such individuals and non-state entities are the concern of the international community (Shearer 1994:3).

A closer look at these definitions reveals more similarities than differences. The use of the clauses/phrases 'a set or body of rules and/or 


\section{H. Puleng Motlalekgosi}

principles which are binding', 'the relationship between two or more parties', and 'individual or human rights' are common in all three definitions. What is interesting and more pertinent to this study in relation to this definition, are the rules and principles of international laws that regulate and shape the behavior of the states, prevent violations by the states, and provide remedies for violations when they occur (Stratton 2009:1), as well as an area of human rights believed to be new - that emerged in the $20^{\text {th }}$ century and deals with the treatment of individuals and groups, international criminal law, and international economic law (Schreuer 2000:2).

In 1945, the UN as international organization charged with the role of promoting and protecting fundamental human rights, amongst others, signed the Charter for the UN which is, amongst others, aimed at encouraging the respect for human rights and for the fundamental freedom for all without distinction of race, sex, language, or religion (United Nations 1945:1). In terms of article $2(\S 2)$ of the Charter, all member states of the UN have to fulfil in good faith the obligations assumed by them in accordance with the Charter. It should be noted that the Charter also entitles member states the rights and benefits resulting from their membership. It is therefore incumbent upon South Africa to fulfil its obligations by virtue of its current membership status to the UN.

In essence, South Africa is directly and indirectly bound by the provisions of all sources of international law, also referred to as international instruments or international bills of rights, and in particular the Universal Declaration of Human Rights (UDHR) (United Nations 1948), the International Covenant on Civil and Political Rights (ICCPR) (United Nations General Assembly 1966), the Basic Principles for the Treatment of Prisoners (United Nations General Assembly 1990), the Rules for the Protection of Juveniles Deprived of their Liberty (United Nations General Assembly 2012), and the United Nations Standard Minimum Rules for the Treatment of Prisoners, also known as the Nelson Mandela Rules (United Nations 2015) - deemed relevant to this study. It is the view of this essay that the foregoing instruments are aimed at giving effect to the purpose of encouraging respect for human rights and fundamental freedoms of the UN Charter which is binding in nature hence the use of direct and indirect obligations of member states to the UN.

The following is an outline of excerpts of rules, principles, and conventions, referred to as international human rights instruments, pertinent to the freedom of religion, that also apply to prisoners. In 1948, the General 
Assembly of the UN adopted and proclaimed the UDHR as a common standard of achievement for all peoples and nations, to the end that every individual and organ of society, keeping this Declaration in mind, has to strive by teaching and education to promote respect for these rights and freedoms (United Nations 1948:3). It is worth noting that when the UDHR was adopted, the Union of South Africa abstained from voting in favor or against the adoption (United Nations 1950:535) in an attempt to protect its system of apartheid (Schifter 1993).

The UDHR is an international legal instrument that articulates the rights that are universal to every individual in the modern concept of rights as defined by the South African Department of Correctional Services (Department of Correctional Services 2013:30). Gleeson (2005) looks at the bigger picture, contending that almost all international human rights instruments adopted by the UN bodies since 1948, are elaborate principles, outlined in the UDHR, while many constitutions of member states, including South Africa, are informed by the UDHR. Pertinent to this essay is article 18 of the UDHR which states that 'everyone has the right to freedom of thought, conscience and religion. This right includes freedom to change his [sic.] religion or belief and freedom either alone or in community with others and in public or private to manifest his [sic.] religion or belief in teaching, practice, worship and observance' (United Nations 1948:4).

In 1966, the General Assembly of the United Nations adopted the ICCPR, which was only ratified by South Africa in 2002. The ICCPR preamble takes cognizance of the role of the UN Charter and the UDHR of making provisions for human rights. Relevant to this study is articles 18 and 27, stating the following:

18. (1) Everyone shall have the right to freedom of thought, conscience and religion. This right shall include freedom to have or to adopt a religion or belief of his [sic.] choice, and freedom, either individually or in community with others and in public or private, to manifest his [sic.] religion or belief in worship, observance, practice and teaching. (2) No one shall be subject to coercion which would impair his [sic.] freedom to have or to adopt a religion or belief of his [sic.] choice.

(3) Freedom to manifest one's religion or beliefs may be subject only to such limitations as are prescribed by law and are necessary to protect public safety, order, health, or morals or the fundamental rights and 
freedoms of others.

27. States in which religious minorities exist, persons belonging to such minorities shall not be denied the right, in community with other members of their group, to practice their own religion (United Nations General Assembly 1966).

It is common knowledge that prisons are closed and secured environments, creating a fertile environment for prison authorities to violate the rights of prisoners. It is therefore of paramount importance that the actions of prison officials be monitored against any violation of prisoners' rights. In line with the UN Charter and UDHR provisions, international human rights instruments such as the Basic Principles for the Treatment of Prisoners (1990), Rules for the Protection of Juveniles Deprived of their Liberty (2012), and the Nelson Mandela Rules (2015), as mentioned above, are important tools that guarantee prisoners' rights at an international level, cascading down to regional and domestic levels. As alluded to in the introductory part, prisoners are also entitled to the right to freedom of religion, of which the following excerpts of the international human rights instruments are an affirmation: The Basic Principles for the Treatment of Prisoners was adopted by the UN General Assembly in 1990 during the $68^{\text {th }}$ plenary session (United Nations General Assembly 1990), believing that this articulation could facilitate the full implementation of the UN Standard Minimum Rules for the Treatment of Prisoners (United Nations 1990). Although not binding in nature to member states, these principles have a great value and an influence on the development of the penal policy and practice (United Nations General Assembly 1990). This can be referred to as an indirect obligation, because member states develop their penal laws and policies with a great deal of consideration of such principles which, in turn, become obligatory to prison authorities. Principle 3 of these principles is articulated in respect to the right of prisoners to freedom of religion, as it states that it is desirable 'to respect the religious beliefs and cultural precepts of the group to which prisoners belong, whenever local conditions so require' (United Nations General Assembly 1990).

The UN Rules for the Protection of Juveniles Deprived of their Liberty was adopted by the UN General Assembly in 1990 during its $68^{\text {th }}$ plenary meeting. The preamble to these rules is a clear demonstration of the extent to which they are consistent with the provisions of the UDHR, ICCPR, and the UN Standard Minimum Rules for the Treatment of Prisoners, amongst others 
(United Nations General Assembly 1990). Member states to the UN have legal obligations related to an adequate protection of the human rights of children deprived of their liberty (United Nations General Assembly 2012). Rule 48 of these rules states the following:

48. Every juvenile should be allowed to satisfy the needs of his or her religious and spiritual life, in particular by attending the services or meetings provided in the detention facility or by conducting his or her own services and having possession of the necessary books or items of religious observance and instruction of his or her denomination. If a detention facility contains a sufficient number of juveniles of a given religion, one or more qualified representatives of that religion should be appointed or approved and allowed to hold regular services and to pay pastoral visits in private to juveniles at their request. Every juvenile should have the right to receive visits from a qualified representative of any religion of his or her choice, as well as the right not to participate in religious services and freely to decline religious education, counselling or indoctrination.

The UN Standard Minimum Rules for the Treatment of Prisoners was initially adopted by the General Assembly in 1955 and then revised in 2015. This revision saw an approval of the recommendation of the expert group established by the General Assembly that these rules be known as the Nelson Mandela Rules (United Nations 2015). Similar to these rules, the development of the Nelson Mandela Rules was guided by the principal purpose of the UN as set out in the preamble of the Charter and the UDHR.

The Nelson Mandela Rules are also not binding in nature. However, due to the fact that they have been universally acknowledged as minimum standard for the detention of prisoners, being of significant value and influence as a guide in the development of correctional laws, policies, and practices, they are somewhat binding, because the very correctional laws and policies of respective member states such as South Africa are legally binding. This can be called an indirect obligation. Rules 65 and 66 state the following (United Nations General Assembly 1990):

65. (1) If the prison contains a sufficient number of prisoners of the same religion, a qualified representative of that religion shall be 


\section{H. Puleng Motlalekgosi}

appointed or approved. If the number of prisoners justifies it and conditions permit, the arrangement should be on a full-time basis.

(2) A qualified representative appointed or approved under paragraph

(1) shall be allowed to hold regular services and to pay pastoral visits in private to prisoners of this religion at proper times.

(3) Access to a qualified representative of any religion shall not be refused to any prisoner. On the other hand, if any prisoner should object to a visit of any religious representative, his [sic.] attitude shall be fully respected.

66. So far as practicable, every prisoner shall be allowed to satisfy the needs of his [sic.] religious life by attending the services provided in the institution and having in his [sic.] possession the books of religious observance and instruction of his [sic.] denomination.

The above outline of international tools and their relevancy to this article is a demonstration of their importance to the realization of promotion and protection of prisoners' freedom of religion, and lays the foundation for such, not only at continental level but also at regional level.

\section{African continental law context}

The African continental system has been developed under the auspices of the Organization of African Unity (OAU), founded in 1963, which was formally transformed into the AU in 2002. The OAU was designed as a regional intergovernmental organization (Dugard 2005:546) with the following objectives:

- to promote the unity and solidarity of the African states;

- to coordinate and intensify their cooperation and efforts to achieve a better life for the peoples of Africa;

- to defend their sovereignty, their territorial integrity and independence;

- to eradicate all forms of colonialism from Africa; and

- to promote international cooperation, having due regard to the Charter of the United Nations and the Universal Declaration of Human Rights (Organization of African Unity 1982). 
In addition to the above objectives, the OAU Charter preamble states that freedom, equality, justice, and dignity are essential objectives for the achievement of the legitimate aspiration of the African people. The above superficial mention of human rights in the provisions of this Charter points to the fact that the OAU was not initially established to promote and protect human rights. The focus was on the dominating concerns of Africa at the time, including the independence of African people who were still colonized, the condemnation of apartheid regimes in Southern Africa, and the protection of a newly acquired statehood (Murray 2004:7). Clearly, the issue of human rights was not going to take center stage when there was an urgent and burning desire for decolonization and a fight against apartheid regimes in Southern Africa, particularly in South Africa.

In addition to the South African issues of apartheid and racial discrimination, the work of the International Labor Organization (ILO) and other international organizations prompted the OAU organs to consider issues like workers' rights from an early stage in its history. Events and conferences held at international level - some of which were held in Africa - in which African states were involved, also prompted the OAU to consider some aspects of human rights. An increased attention to human rights saw an encouragement at the UN level for regional human rights mechanisms and a recognition by some African leaders that human rights in a specific state were also their concern, and this led to the adoption of the African Charter on Human and Peoples' Rights (ACHPR) in 1981, also known as the Banjul Charter (Murray 2004:21). Mansell and Openshaw (2013:146) believe that the implementation of regional protection mechanisms is a result of problems of enforcement on a global level.

The ACHPR preamble acknowledges that fundamental human rights stem from the attributes of human beings as it justifies their national and international protection, and that the reality and respect of peoples' rights should necessarily guarantee their human rights. Furthermore, it reaffirms the adherence of members of the African states to the principles of human and peoples' rights and freedoms contained in the declarations, conventions, and other instruments adopted by the OAU, the Movement of Non-Aligned Countries, and the UN. Article 1 of the ACHPR states that 'member States to the OAU parties to the present Charter shall recognize the rights, duties and freedoms enshrined in this chapter and shall undertake to adopt legislative or other measures to give effect to them' (Organization of African Unity 1982:2). 


\section{H. Puleng Motlalekgosi}

The adoption of the ACHPR was indeed an African milestone, let alone the subsequent adoption of protocols to it. The adoption of the ACHPR was necessary to give effect to the UN Charter, UDHR, ICCPR, and other international instruments as stated above. The reaffirmation of the member states of the OAU to the adherence of the principles of human and people's rights, could be construed as an agreement to be bound by the provisions of the ACHPR. This is consistent with article 25 of the ACHPR hinting that this Charter is obligatory. South Africa signed and ratified the ACHPR in 1996 and therefore must comply with its provisions. Relevant to this study is article 8 which states that 'freedom of conscience, the profession and free practice of religion shall be guaranteed. No one may, subject to law and order, be submitted to measures restricting the exercise of these freedoms' (Organization of African Unity 1982). The focus now moves to the prisoners' freedom of religion within the South African context.

\section{Domestic law context}

As alluded to in the above discussion, South Africa is a member state of the $\mathrm{UN}$ and the AU and is therefore expected to observe and comply with the provisions of the Charters and conventions of both these bodies. This means that it is an obligation for South Africa to institute measures to give effect to these provisions of the UN and AU. This could be seen in the promulgation of the interim Constitution of 1993 after extensive constitutional talks to discuss, amongst others, a united South Africa, sharing a common citizenship, the healing of the divisions of the past, and the creation of an environment, helpful to peaceful constitutional change, by eliminating violence and promoting free political participation, discussion, and debate (United Nations Peacemaker 1991).

This Constitution was duly endorsed by the last apartheid Parliament and became the Constitution of the Republic of South Africa, Act 200 of 1993. What is significant about it is that it made provision for civil and political rights as it contained the Bill of Rights, which guarantees the right of every individual to be protected by the international human rights conventions. It provides that every individual shall enjoy all the universally accepted fundamental rights, 
freedoms, and liberties (South Africa 1993) ${ }^{1}$. Two years after the dawn of democracy in South Africa, the Constitution of the Republic of South Africa of 1996 was mistakenly promulgated as an Act of parliament (Act 108 of 1996), but later corrected to become the supreme law of South Africa (Van Heerden 2007:40). Chapter 2 of this Constitution makes provision for the Bill of Rights, explained by section 7 below (South Africa 1996):

7. (1) This Bill of Rights is a cornerstone of democracy in South Africa. It enshrines the rights of all people in our country and affirms the democratic values of human dignity, equality and freedom.

(2) The state must respect, protect, promote and fulfil the rights in the Bill of Rights.

(3) The rights in the Bill of Rights are subject to the limitations contained or referred to in section 36, or elsewhere in the Bill.

It is also important to note that section 231(5) of this Constitution is explicit in terms of the obligation that South Africa has in respect of its international agreement, as it states that South Africa is bound by international agreements when the Constitution takes effect. Pertinent to this study are sections 15 and 31 of the Constitution which are binding to the state, state agencies, and state machinery, such as the Department of Correctional Services. These sections make provision for the right to freedom of religion and the right to religious communities respectively, stating the following (South Africa 1996):

15. (1) [E]veryone has the right to freedom of conscience, religion, thought, belief and opinion.

(2) $[R]$ eligious observances may be conducted at state or state-aided institutions, provided that (a) those observances follow rules made by the appropriate public authorities; (b) they are conducted on an equitable basis; and (c) attendance at them is free and voluntary.

31. (1) Persons belonging to a cultural, religious or linguistic community may not be denied the right, with other members of that community (a) to enjoy their culture, practise their religion and use

\footnotetext{
1 In the meantime, the Constitution of the Republic of South Africa, Act 200 of 1993, has been repealed.
} 


\section{H. Puleng Motlalekgosi}

their language; and (b) to form, join and maintain cultural, religious and linguistic associations and other organs of civil society.

To give effect to these provisions, the South African Department of Correctional Services promulgated Correctional Services Act 111 of 1998 as amended (Department of Correctional Services 1998) and the White Paper on Corrections of 2005 (Department of Correctional Services 2005). In terms of section 2(b) of the Correctional Services Act, the purpose of the correctional system of South Africa is to contribute to maintaining and protecting a just, peaceful, and safe custody by, inter alia, detaining all inmates in safe custody, whilst ensuring their human dignity. Furthermore, section 14 of this Act makes provision for the right to freedom of religion, belief, and opinion, stating the following (Department of Correctional Services 1998):

14. (1) An inmate must be allowed freedom of conscience, religion, thought, belief and opinion.

(2) An inmate may attend religious services and meetings held in the prison freely and voluntarily and may have in his or her possession religious literature.

(3) Where practicable, places of worship must be provided at every prison for prisoners of religious denominations.

(4) No inmate may be compelled to attend religious services or meetings or to take part in religious practices.

The above section should be read in conjunction with the following sections of the same Act, because the two sections are advocating for the spiritual wellbeing of inmates:

8. (3) [W]here reasonably practicable, dietary regulations must take into account religious requirements.

13. (2) $[\mathrm{T}]$ he Department must give inmates the opportunity to communicate with and being visited by chosen religious councillors.

19. (2) [T] he national commissioner must provide every child inmate with religious care.

38. (1) [A]s soon as possible after admission as a sentenced offender, such offender must be assessed to determine his or her religious needs. 
134. (2) [T]he national commissioner may issue orders, not inconsistent with this Act and regulations made, which must be obeyed by all correctional officials and other persons to whom such orders apply as to the wearing of attire for religious purposes (Department of Correctional Services 1998).

Paragraph 9.7.2 of the White Paper on Corrections also makes provision for the right of prisoners to freedom of religion as it states that a correctional sentence-plan should be based on the total needs of the specific offender, which includes, inter alia, the needs in terms of the emotional well-being of the offender. Although the Correctional Services Regulations of 2004 as amended in 2012 (Department of Correctional Services 2012) do not make provision for the requirements of the prisoners' freedom of religion, an untraceable 2002 internal policy on spiritual care referenced by Landman, Luyt and Du Preez $(2006)^{2}$ can be regarded as the first formal and tangible religious internal policy giving effect to the foregoing provisions of the law in the democratic dispensation. In 2006, the Department of Correctional Services approved an internal policy on Offender Development and Care and its objectives include, amongst others, the enhancement of the personal well-being of offenders through the provision of spiritual care services underpinned by the principle of accessibility (Department of Correctional Services 2006).

\section{The period between 1997 and 2016: Prisoners' freedom of religion in South Africa}

The state of affairs in respect of prisoners' freedom of religion in South Africa is one that can be described in two dimensions. The one dimension is based on the official departmental annual reports and the other dimension on prison conditions that militate against the purpose of the correctional system of South

2 Landman, Luyt \& Du Preez (2006) contest that this policy is compromised by two factors, namely 1) the department's Directorate of Spiritual Care has only 26 fulltime official prison chaplains in its service to minister to 240 prisons. Therefore, religious work in prisons is dependent on the work of voluntary spiritual workers; and 2) prisoners do not see religion as falling within their rights as bodily beings, but as a conflict between souls and dogmatic truths. 


\section{H. Puleng Motlalekgosi}

Africa as required by law, that the detention of all inmates must meet the requirement of safe custody whilst ensuring their human dignity.

For the purpose of this study, the annual reports under the spotlight are those published between 1997 and 2016. According to the Department of Correctional Services' annual report of 1997, religious care programs for inmates in South Africa was done through the involvement of various religious communities, and this was regarded as an important component of this service, as a network of 1,991 religious workers from 71 different churches and religions was established (Department of Correctional Services 1997). Services rendered in the religious care program included large group gatherings, small group sessions, and personal interviews for inmates. 27,027 large group gatherings, 20,422 small group sessions, and 23,490 personal interviews were conducted, all with the involvement of religious workers and chaplains (Department of Correctional Services 1997).

Two years later, the Department reported in its 1999 annual report that it had the services of 2,096 religious workers, representing 71 different churches. 33,158 large group gatherings, 22,025 small group sessions, and 46,153 personal interviews were conducted, all with the involvement of religious workers and chaplains (Department of Correctional Services 1999). According to the 2003/2004 annual report, religious and spiritual care services covered a broad spectrum of the inmates' spiritual needs on a personal and communal level. Personal spiritual needs received attention in individual conversations and small group meetings with the chaplain and/or spiritual workers, with the following intended objectives:

- the offender's experience of his/her punishment, his/her adaptation to life in the correctional facility and the process of leading him/her to a life free from criminality;

- support in times of crisis and with regard to problems pertaining to his/her faith; and

- recovery and maintenance of his/her relationship with him-/herself, his/her marriage partner, family, extended family and friends, the Creator and nature (Department of Correctional Services 2004).

The communal experience of faith received attention through large group gatherings with the following objectives:

- fellowship in the greater group; 
- expansion of knowledge of that faith; and

- the communal practice of spiritual customs and rituals (Department of Correctional Services 2004).

In its 2007/2008 annual report, the Department of Correctional Services succinctly outlined a strategic objective in promoting the right to freedom of religion. This strategic objective provided a comprehensive needs-based care program to ensure the well-being of people in the Department's care. Its measurable objective was the number of offenders participating in spiritual care programs and services. Interestingly, the target set was 165,700 and it was exceeded by 256 inmates (Department of Correctional Services 2008). According to the Department of Correctional Services' strategic plan for the period between 2010/2011 to 2014/2015 (Department of Correctional Services 2011b), a measurable objective in respect of the promotion of the right to freedom of religion was to ensure the personal well-being of incarcerated people by providing various needs-based services. The strategy was to implement spiritual care needs-based programs and an impact instrument in two management areas per region during the 2010/2011 financial year (Department of Correctional Services 2011a).

In its 2010/2011 annual report, the Department managed to implement $53.8 \%$ ( 7 out of 13) spiritual care programs from a target of $69.2 \%$ (9 of 13). The target for inmates' participation in the spiritual care programs was $51.29 \%$ $(83,822$ out of 163,427 offenders). Interestingly, the target was exceeded as the Department achieved 55.16\% (90,151 offenders). Furthermore, a spiritual care data collection tool was reviewed, consulted, and finalized for implementation. A total number of 51 officials, including the Regional Heads of Development and Care Coordinator Chaplains, were trained to implement the tool in regions. The new program, Building Healthy Relationships, was developed. 61 officials were trained for the implementation of the spiritual care pre-release and anger management programs in three regions. The Spiritual Care Family Life Program was piloted in Boksburg and Zonderwater management areas. 198,859 spiritual care sessions were held, including 54,003 church/faith services, 51,266 group sessions, and 93,590 individual pastoral sessions with a target of 185,000 sessions (Department of Correctional Services 2011a).

In terms of the Department's strategic plan of 2013/2014 to 2016/2017 (Department of Correctional Services 2014b), the strategic objective to 


\section{H. Puleng Motlalekgosi}

promote the right to freedom of religion was to correct the offenders' behavior through access to correctional programs and spiritual services (Department of Correctional Services 2014b). According to the 2013/2014 annual report, the Department has set a target of $52 \%(81,035$ out of 155,836$)$ of inmates to have access to spiritual care services. However, the Department achieved $77.77 \%$ (120,668 out of 155,169 inmates) (Department of Correctional Services 2014a).

Although the Department's strategic plan of 2015/2016 to 2019/2020 has clearly outlined its strategic objective of correcting offenders' behavior through access to spiritual services (Department of Correctional Services 2015 b), there were no targets set to achieve this objective, and yet the Department claimed to have achieved all targets relating to spiritual care services. This was based on the data provided in the Department's annual report which indicated a target of $54 \%$, translating to 83,310 out of 154,278 prisoners to be achieved in 2014/2015. However, a total of $83.87 \%$, translating to 133,826 out of 159,563 prisoners, which is a real achievement, had access to spiritual services (Department of Correctional Services 2015b).

As mentioned above, section 2(b) of the Correctional Services Act has put a legislative mandate on the South African Department of Correctional Services of detaining all inmates in safe custody whilst ensuring their dignity. This is consistent with section 10 of the Constitution which states that everyone has an inherent dignity and the right to have their dignity respected and protected. Section 1 further states that human dignity is the founding value of South Africa.

In 1995, the Constitutional Court of South Africa made a historical judgment about the value and the importance of the right of human dignity in the case of $S v$ Makwanyane (SAFLII 1995), stating that the right to human dignity is the foundation of many of the other rights that are specifically entrenched in the Bill of Rights ${ }^{3}$. Many scholars concur with the Constitutional Court judgment that pursues the importance and the value of the right to human dignity. For instance, Currie and De Waal (2005:273) assert that human dignity is the source of a person's innate right to freedom and to physical integrity from which a number of other rights flows. Muntingh (2007:11) posits that the

3 In Sv Makwanyane 1995 (3) SA 391 (CC), the court heard extensive submissions in respect of the right to human dignity, including references to the fact that this right is fundamental and central to every other right entrenched in the Bill of Rights. 
right to human dignity lies at the core of prisoners' rights in a constitutional democracy. Luyt, Jonker, and Bruyns (2010:200) regard human dignity as central to and the foundation of all fundamental rights.

It is against the foregoing backdrop that prisoners' rights of freedom of religion cannot be separated from the right to human dignity. Therefore, it suffices to say that the protection and promotion of the prisoners' freedom of religion must also be measured against the right to human dignity. In other words, a violation of the right to human dignity could amount to a violation of the right of prisoners to freedom of religion and vice versa.

It is not the intention of this essay to dwell on a discussion about the conditions in South Africa's prisons, but it is important to give a general overview pertaining to it. South Africa's prison system is faced with many challenges including overcrowding and understaffing. In its 2015/2016 annual report, the Department of Correctional Services acceded that the percentage of overcrowding in prisons and remand detention facilities was in excess of the approved capacity, despite an allocation of an almost R2 million budget specifically for an offender management program (Department of Correctional Services 2016:33).

In its 2014/2015 annual report, the Department reported that they had to accommodate 157,141 prisoners in a space that could only accommodate 119,134 prisoners (Department of Correctional Services 2015a). This represented a capacity deficit of 38,007 , translating into an overpopulation of $31.9 \%$. In March 2016, the Department had 161,779 prisoners in its facilities (Judicial Inspectorate for Correctional Services 2016) against the lockup capacity of 114,822 (Department of Correctional Services 2009:8). This data represented a capacity deficit of 46,957, translating into an overpopulation of $40.89 \%$.

According to the Department of Correctional Services 2014/2015 annual report, its staff establishment was 42006 , with 38,440 of these positions filled and 3,566 vacant, representing an $8.5 \%$ vacancy rate (Department of Correctional Services 2015a). In March 2016, the filled post establishment of the South African Department of Correctional Services was 38,226 against an approved funded post establishment of 42,006 (Department of Correctional Services 2016). This means that 3,780 funded posts were not filled - a vacancy rate of $9 \%$. 


\section{H. Puleng Motlalekgosi}

\section{Analysis}

Sections 15 and 31 of the Constitution, as discussed under the domestic law section above, are a reflection of an elaboration of international human rights instruments adopted by the UN bodies. It essentially gives effect to the international human rights instruments and within that framework, it makes provision for the promulgation of correctional laws and policies which are binding. In other words, international human rights instruments such as the Nelson Mandela Rules which are not binding in nature, become binding at national level, because it has a significant value and influence on the development of correctional laws and policies which are binding. As already mentioned, this can also be called an indirect obligation.

The value and influence of such international human rights instruments are reflected in sections 8, 13, 14, 19, 38, and 134 of the Correctional Services Act and paragraph 9.7.2 of the White Paper on Corrections. In light of the above discussion, it is clear that more still needs to be done in respect of the 2004 correctional services regulations and the 2006 departmental internal policy on Offender Development and Care to address issues related to prisoners' freedom of religion. While the correctional services regulations are mum about prisoners' freedom of religion, the 2006 internal policy on Offender Development and Care is not clear in terms of how religious tenets of various religious groups should be observed, exercised, and practiced. While this policy refers to various groups and church gatherings, it is not specific as to whether these are Christians, Jews, Muslims, Rastafarians, or others (Department of Correctional Services 2006).

Notwithstanding an official recognition of the Muslim religion by the South African correctional services, through a memorandum of understanding with the National Muslim Prison Board of South Africa (Department of Correctional Services 2014c) as well as the ever-increasing numbers of nonChristian prisoners having access to spiritual services, the Department is seemingly still biased towards Christianity. Christian faith groups would mostly meet in small or large group gatherings and this is basically used as a yardstick to measure the departmental performance in respect of the protection and promotion of the right of prisoners to freedom of religion.

The right of prisoners to freedom of religion extends beyond gatherings and the appointment and training of chaplains. For instance, the Commission for the Promotion and Protection of the Rights of Cultural, Reli- 
gious and Linguistic Communities recommended, amongst others, that correctional services should provide the Rastafarian inmates with a proper Ital diet in prison, not forcing them to cut their hair and beard (Commission for the Promotion and Protection of the Rights of Cultural, Religious and Linguistic Communities 2012). The question as to whether these recommendations are considered and implemented by the Department remains to be seen, as these are not incorporated in the departmental policies on religion.

In light of the above-mentioned information, it is ironic that, in the face of an increasing number of prisoners in South African prisons between 2015 and 2016, there was also an increasing staff vacancy rate. Perhaps it is time to suggest solutions about the determination of a number of approved funded positions in the Department as it remains stagnant even when circumstances change.

Should the Department's performance in terms of protection and promotion of prisoners' freedom of religion be measured, it is obvious that, from a legislative and policy point of view, the Department is not fully compliant with the requirements of international and African continental laws, as there is an immediate need to review its current internal policy on the right of prisoners to freedom of religion and correctional services regulations. If the departmental strategic plans and annual reports as discussed above, are to be taken at face value, it appears that the Department is doing enough to protect and promote the right of prisoners to freedom of religion. However, like many rights entrenched in the Bill of Rights, the right of prisoners to freedom of religion must also be measured against the right to human dignity which is hampered by challenges of overcrowding and understaffing in South Africa's prisons as demonstrated in the preceding section.

It is almost impossible to allocate a certain number of officials to cater for the special needs (such as special diets) of religious groups such as the Rastafarians and Muslims, as opposed to Christians, due to staff shortages, for instance. This is, according to the Judicial Inspectorate for Correctional Services, a primary source of stress amongst correctional officials (Judicial Inspectorate for Correctional Services 2016). Linked to this, overcrowding violates prisoners' rights as it limits their personal space and privacy. This submission is consistent with the assertion of Giffard and Muntingh (2006:16) that different approaches to space utilization will impact differently on a prisoner's lived experience of overcrowding. This begs the question as to how 


\section{H. Puleng Motlalekgosi}

one could ensure that prisoners observe and practice their religious tenets privately, as prescribed by law, when there is a lack of space.

Most of the South African prisons are only designed for the purpose of housing prisoners and consist of nothing more than cells and corridors (Giffard \& Muntingh 2006:16). It is clear that, in addition to the two intrinsic factors of overcrowding and understaffing, the architecture of prisons impinges on the right of prisoners to freedom of religion and subsequently on the right to human dignity. Therefore, the South African Department of Correctional Services is a violator of the Constitution which guarantees the right of prisoners to freedom of religion. We are certainly not there yet.

\section{Conclusion}

It is an undeniable fact that in a functionally constitutional democratic society like South Africa that is based on human dignity, equality, and freedom, prisoners should be entitled to freedom of religion. What prison authorities do to ensure the respect, protection, and promotion of prisoners' freedom of religion must be consistent with the provision of not only the Constitution, but also international laws and African continental laws. Prisoners must be afforded an opportunity to choose to exercise this right without prejudice or influence from prison officials. This could mean that prison authorities should identify activities that they must undertake to ensure that the freedom of religion of prisoners is respected, protected, and promoted, and incorporate them in their internal policies.

It is also important that prison authorities and the communities they serve, including prisoners, take cognizance of the fact that the freedom of religion of prisoners is in fact a sensitive matter and must be cautiously dealt with. This will ensure that all those who are incarcerated, feel free to congregate and praise and worship according to the tenets of their choice. In South Africa, prisoners are afforded an opportunity to gather and worship according to their religious tenets. Evidentially, there is an ever-increasing number of prisoners attending religious gatherings, as well as the involvement of religious workers and chaplains, according to the annual reports of the Department, but are these sufficient enough to firmly state that the Department is protecting and promoting the right of prisoners to freedom of religion? It 
would be a mistake not to consider other important factors in answering this question.

The challenges of overcrowding and understaffing make it difficult to arrive at a conclusion that the Department is protecting and promoting the right of prisoners to freedom of religion. As such, it also impacts their right to human dignity. In fact, it appears that the Department seems to be inconsiderate of its legislative mandate, including the treatment of prisoners that ought to be consistent with the principles of human dignity. Therefore, the right of prisoners to freedom of religion in South Africa is currently more a pipe dream than a reality.

This essay suggests that the Department should read the provisions of international and African regional instruments with an understanding that domestic laws, including the correctional services regulations and internal policies, must adequately address the right of prisoners to freedom of religion. This will enable an understanding that this right cannot be separated from the right to human dignity and thereby complying with the Correctional Services Act. Furthermore, the Department is requested to immediately fill vacant positions and continue to intensify its efforts to deal with overcrowding, which can also be achieved through the architectural redesigning of all prisons across the country.

\section{References}

African Union. 2019. African Union handbook 2019. Addis Ababa: African Union Commission and New Zealand Ministry of Foreign Affairs and Trade.

Aust, A. 2010. Handbook of international law. Cambridge: Cambridge University Press.

Brierly, J.L. 1963. The law of nations: An introduction to the international law of peace. Glasgow: Oxford University Press.

Commission for the Promotion and Protection of the Rights of Cultural, Religious and Linguistic Communities. 2012. Challenges faced by the Rastafari community. Johannesburg: CRL Rights Commission.

Currie, I. \& J. De Waal 2005. The Bill of Rights handbook. $5^{\text {th }}$ ed. Cape Town: Juta \& Co. Ltd. 
Department of Correctional Services. 1997. 1997 annual report. Pretoria:

Department of Correctional Services.

Department of Correctional Services. 1998. Correctional Services Act 111 of 1998 amended by Act 25 of 2008. Government Gazette 521, 31593.

Department of Correctional Services. 1999. 1999 annual report. Pretoria: Department of Correctional Services.

Department of Correctional Services. 2004. 2003-2004 annual report. Pretoria: Department of Correctional Services.

Department of Correctional Services. 2005. White Paper on Corrections, 2005.

Pretoria: Department of Correctional Services.

Department of Correctional Services. 2006. Offender Development and Care Policy. Pretoria: Department of Correctional Services.

Department of Correctional Services. 2008. 2007-2008 annual report.

Pretoria: Department of Correctional Services.

Department of Correctional Services. 2009. National offender population profile in the Department of Correctional Services. Pretoria: Department of Correctional Services.

Department of Correctional Services. 2011a. 2010-2011 annual report. Pretoria: Department of Correctional Services.

Department of Correctional Services. 2011b. 2010/2011-2014/2015 strategic plan. Pretoria: Department of Correctional Services.

Department of Correctional Services. 2012. Correctional Services Regulations. Pretoria: Department of Correctional Services.

Department of Correctional Services. 2013. Draft white paper on remand detention management in South Africa. Pretoria: Department of Correctional Services.

Department of Correctional Services. 2014a. 2013-2014 annual report. Pretoria: Department of Correctional Services.

Department of Correctional Services. 2014b. 2013/2014-2016/2017 strategic plan. Pretoria: Department of Correctional Services.

Department of Correctional Services. 2014c. Correctional Services signs memorandum of understanding with the National Muslim Prison Board of South Africa. Press release. Available at: http://www.gov.za/judgesiraj-desai-praises-signing-mou-correctional-services-and-nationalmuslim-prison-board-south. (Accessed on 3 November 2017.)

Department of Correctional Services. 2015a. 2014-2015 annual report. Pretoria: Department of Correctional Services. 
Department of Correctional Services. 2015b. 2015/2016-2019/2020 strategic plan. Pretoria: Department of Correctional Services.

Department of Correctional Services. 2016. 2015-2016 annual report. Pretoria: Department of Correctional Services.

Devenish, G.E. 1999. A commentary on the South African Bill of Rights. Durban: Butterworth.

Dugard, J. 2005. International law: A South African perspective. Cape Town: Juta \& Co. Ltd.

Dugard, J. 2011. International law: A South African perspective. $4^{\text {th }}$ ed. Cape Town: Juta \& Co. Ltd.

Giffard, C. \& L. Muntingh 2006. The effect of sentencing on the size of the South African prison population. Cape Town: Open Society Foundation for South Africa.

Gleeson, K. 2005. Worldwide influence of the Universal Declaration of Human Rights and the international Bill of Rights. Available at: http://www.universalrights.net/main/world.htm. (Accessed on 5 March 2018.)

Judicial Inspectorate for Correctional Services. 2016. Annual report for the period 01 April 2015 to 31 March 2016. Available at: http://judicialinsp.dcs.gov.za/Annualreports/JICS\%20Annual\%20Repo rt\%20\%202015-2016\%20as\%20at\%204\%20October\%202016\%20v\% 2012.pdf. (Accessed on 5 December 2017.)

Landman, C., W. Luyt \& N. Du Preez 2006. The incarcerated body: Judicial inspections, human rights and religious policy in prisons in South Africa. Studia Historiae Ecclesiasticae 32, 2: 321-343.

Luyt, W., J. Jonker, \& H. Bruyns 2010 Unit management \& legal principles in prisons. Pretoria: UNISA Press.

Mansell, W. \& K. Openshaw 2013 International law: A critical introduction. Oxford: Hart Publishing.

Muntingh, L. 2007. Prisons in the South African constitutional democracy. Braamfontein: Centre for the Study of Violence and Reconciliation.

Murray, R. 2004. Human rights in Africa: From the OAU to the African Union. Cambridge: Cambridge University Press.

Organization of African Unity. 1982. African Charter on Human and Peoples' Rights ('Banjul Charter'), 27 June 1981, CAB/LEG/67/3 rev. 5, 21 I.L.M. 58 (1982). Available at: http://www.refworld.org/docid/3ae6b 3630.html. (Accessed on 24 March 2018.) 
Schifter, R. 1993. Human rights at the United Nations: The South African precedent. American University International Law Review 2, 8: 361372.

Schreuer, C. 2000. Sources of international law: Scope and application. Emirates lecture series 28. Abu Dhabi: The Emirates Centre for Strategic Studies and Research.

Shearer, I.A. 1994. Starke's international law. London: Butterworth.

South Africa. 1993. Act 200 of 1993: Constitution of the Republic of South Africa. Pretoria: Government Printers.

South Africa. 1996. The Constitution of the Republic of South Africa as adopted by the Constitutional Assembly on 8 May 1996 and amended on 11 October 1996. Pretoria: Government Printers.

Stratton, J. 2009. Hot topics 69: Legal issues in plain language. Sydney: Legal Information Centre.

Supreme Court of Canada. 1985. R v Big M Mart Ltd 1985 (1) SCR 295-336. Available at: https://scc-csc.lexum.com/scc-csc/scc-csc/en/43/1/document.do. (Accessed on 16 October 2018.)

United Nations. 1945. Charter of the United Nations and statute of the international court of justice. San Francisco: United Nations Publications. URL: https://treaties.un.org/doc/publication/ctc/uncharter.pdf

United Nations. 1948. Universal Declaration of Human Rights. Available at: https://www.jus.uio.no/lm/un.universal.declaration.of.human.rights.19 48/portrait.a4.pdf. (Accessed on 16 October 2018.)

United Nations. 1950. Yearbook of the United Nation 1948-49. New York: United Nations Publications.

United Nations. 2015. United Nations standard minimum rules (the Nelson Mandela rules), GA Res 70/175, $17^{\text {th }}$ Sess, Agenda Item No 106, UN Doc A/RES/70/175, 17 December 2015. Available at: https://www. unodc.org/documents/justice-and-prison-reform/GA-RESOLUTION/E _ebook.pdf. (Accessed on 16 October 2018.)

United Nations General Assembly. 1966. International covenant on civil and political rights, 16 December 1966. United Nations Treaty Series 999:

171. URL: http://www.refworld.org/docid/3ae6b3aa0.html

United Nations General Assembly. 1990. Basic principles for the treatment of prisoners. 68 ${ }^{\text {th }}$ Plen Mtg, UN Doc A/RES/45/111, 14 December 1990. Available at: https://www.ohchr.org/EN/ProfessionalInterest/Pages/ 
BasicPrinciplesTreatmentOfPrisoners.aspx. (Accessed on 16 October 2018.)

United Nations General Assembly. 2012. Report of the High Commissioner for Human Rights on the protection of human rights of juveniles deprived of their liberty. Human Rights Council $21^{\text {st }}$ session. Agenda item 1 and 2, UN Doc A/HRC/21/26, 13 August 2012. Available at: https://www.ohchr.org/Documents/HRBodies/HRCouncil/RegularSess ion/Session21/A-HRC-21-26_en.pdf. (Accessed on 17 October 2018.)

United Nations Peacemaker. 1991. CODESA declaration of intent. Available at: https://peacemaker.un.org/southafrica-codesa-intent1991. (Accessed on 13 May 2019.)

Van Heerden, M. 2007. The 1996 Constitution of the Republic of South Africa: Ultimately supreme without a number. Politeia 26, 1: 33-44.

H. Puleng Motlalekgosi Department of Safety and Security Management Tshwane University of Technology motlalekgosid@tut.ac.za 